\title{
Wybrane psychologiczne metody jakościowe stosowane w badaniach nad tekstem pisanym
}

DOI: 10.19195/2083-7763.7.7

\section{Wprowadzenie}

Mogłoby się zdawać, że pamiętniki, dzienniki, listy - jako dokumenty osobiste — to cenne i interesujące źródło danych dla psychologa. Jednak znalezienie współczesnej publikacji, której autorzy wykorzystywaliby taki materiał badawczy, okazuje się trudne. Nasuwają się dwa powody takiego stanu rzeczy: psychologowie wolą mieć do czynienia z żywym człowiekiem, a nie z jego wytworem lub/i problemy metodologiczne związane $\mathrm{z}$ wykorzystaniem dokumentów osobistych w psychologii są na tyle duże, że zniechęcają do zajmowania się tym rodzajem danych. Tym bardziej godne uwagi są współczesne dokonania psychologów podejmujących się tego trudnego zadania. Współczesna psychologia akademicka zdominowana jest przez podejście scjentystyczne, a termin „interpretacja” kojarzy się najczęściej z wyjaśnieniem ilościowych wyników badań w ramach przyjętej teorii zmierzających do ustalenia statystycznych prawidłowości (opis) czy doprecyzowania modelu wyjaśniającego mechanizm zarejestrowanych zmian (wyjaśnianie). Natomiast w podejściu interpretatywnym celem badacza jest odkrycie sensu, czyli rozumienie. Ten cel realizowany jest przez interpretację tekstu, przy założeniu, że symbolizuje on znaczenia (sensy), których jest nośnikiem (Straś-Romanowska 2000). Metody jakościowe, interpretatywne, a w związku z tym osadzone w nurcie humanistycznym, nie należą do głównego nurtu badań psychologicznych. Na negatywne konsekwencje tego stanu rzeczy wskazuje od początku lat dziewięćdziesiątych M. Straś-Romanowska (1992, 2000), uzasadniając konieczność obecności podejścia jakościowego w badaniach psychologicznych, zwłaszcza w psychologii osobowości. Popularne w latach osiemdziesiątych i dziewięćdziesiątych w naukach społecznych badania narracyjne 
pojawiły się również $\mathrm{w}$ psychologii ${ }^{1}$, ale - pomimo apeli o uzupełnianie badań ilościowych jakościowymi - należą raczej do niszowych. Dokumenty pisane, jakkolwiek rzadko, wykorzystywane są jako źródło danych w obu podejściach. Mimo że się od siebie różnią, metody analizy tekstu są często takie same a rezultaty badawcze - zwłaszcza w podejściu ilościowym - okazują się użyteczne dla dokonywanych $\mathrm{w}$ ramach podejścia jakościowego interpretacji.

Celem niniejszego artykułu jest przedstawienie wybranych metod analizy tekstu, przykładów zastosowań i rezultatów badawczych w podejściu jakościowym (interpretatywnym). Stanowić mogą one podpowiedź w poszukiwaniach własnych rozwiązań badawczych. Jako jedno z możliwych rozwiązań została przedstawiona szczegółowo autorska analiza wspomnień pisanych, inspirowana badaniami D. McAdamsa (2001) nad tożsamością narracyjną. Pominięte zostały dokonania w ramach nurtu psychodynamicznego (psychoanaliza w różnych odmianach), jako że jest to podejście odrębne, a co za tym idzie - wymagające oddzielnego potraktowania. W przeglądzie uwzględnione zostały pionierskie badania biograficzne Ch. Bühler (1999) z lat trzydziestych ubiegłego wieku oraz współczesne prace jakościowe wykorzystujące tekst pisany jako materiał badawczy. Źródłem współczesnych prac (opublikowanych po 2005 roku) była baza EBSCO, dokonano także przeglądu zawartości trzech ostatnich roczników czasopism poświęconych badaniom jakościowym - „Qualitative Psychology” oraz „Qualitative Research in Psychology"2.

Narracyjne badania jakościowe w polskiej psychologii dotyczą przede wszystkim tekstów mówionych (Kruchowska 2010; Opoczyńska 2008; Bartosz 2002; Żurko 2008). Nieliczne analizy tekstu pisanego należą do nurtu badań paradygmatycznych, ukierunkowanych na klasyfikowanie narracji, ustalanie związków przyczynowo-skutkowych oraz testowanie hipotez w celu dokonywania uogólnień (Wójcik, Dryll 2008; Jasielska 2010; Dryll 2010; Gawda 2010; Cierpka 2004). $\mathrm{Z}$ tych względów w niniejszym omówieniu brakuje prac polskich badaczy.

\section{Przegląd badań}

Najważniejszym wyróżnikiem tego podejścia jest ukierunkowanie na odkrywanie symboliki tekstu. Dlatego też wszystkie sposoby pracy nad tekstem — zarówno

\footnotetext{
${ }^{1}$ Metody narracyjne w psychologii stosowane są w badaniach osobowości (tożsamość narracyjna), rozwoju dziecka, relacji interpersonalnych, zaburzeń psychicznych i monitorowaniu postępów w terapii, w psychologii zdrowia i in. Osadzone są w różnorodnych podejściach teoretycznych. $\mathrm{W}$ niniejszym artykule przedstawione zostały narracyjne badania historii życia dlatego, że w tego rodzaju badaniach wykorzystywane są dokumenty osobiste (dzienniki, wspomnienia). Nie oznacza to, że metody narracyjne są tym samym co metody badania historii życia.

${ }^{2}$ Omówione zostały wszystkie raporty z badań spełniające przyjęte kryteria: podejście interpretatywne, tekst pisany jako źródło danych, opublikowane po 2005 roku.
} 
nad formą językową oraz strukturą, jak i analizą treści - zmierzają do ustalenia symbolicznego przekazu, którego nośnikiem jest tekst. Badacze traktują opowieść jako tekst Osoby, jako sposób wyrażenia siebie jako osobowej całości. Historycznie biorąc, do najokazalszych dokonań w zakresie badań nad pamiętnikami i dziennikami należy opublikowana w 1933 roku koncepcja biegu życia ludzkiego Ch. Bühler (1999). Wraz ze swoim zespołem zanalizowała ona 200 biografii pisanych wybitnych postaci z przełomu XIX i XX wieku z Europy i USA. Pod uwagę wzięto także dorobek tych osób oraz dane medyczne. Materiał uzupełniono transkrypcjami 50 wywiadów mówionych (pensjonariusze austriackich domów opieki). Biografie były opracowywane w czterech aspektach: biologicznym, biograficznym (wydarzenia), przeżyciowym (psychologicznym) i w aspekcie dzieła (dokonania). Autorka prezentuje całościowe, holistyczne podejście do biografii i do biegu życia. Humanistyczne inklinacje modelu widoczne są także w tematyce aspektu przeżyciowego. Dotyczy on problematyki odkrywania i przeżywania przeznaczenia rozumianego jako osobiste zobowiązanie do działania na rzecz realizacji wartości wykraczających poza indywidualną egzystencję. Zaproponowane zostały etapy rozwoju przeznaczenia, dwa sposoby jego przeżywania (pasywno-czerpiący i aktywno-ustanawiający) oraz uwarunkowania niepowodzeń i trudności w jego odkrywaniu. W dokonywanych analizach i interpretacjach aspektu przeżyciowego brano pod uwagę przede wszystkim komentarze ich autorów do opisywanych wydarzeń, starano się o oddanie towarzyszących wydarzeniom uczuć i przemyśleń. Poszczególne elementy modelu biegu życia autorka ilustruje, streszczając biografie (lub ich części) oraz przytaczając ich fragmenty. Aspekty analizy biografii są wzajemnym kontekstem interpretacyjnym.

Dzienniki stały sięźródłem współczesnych badań w obszarze strategii radzenia sobie w sytuacjach ekstremalnych. B.J. Cohler (2012) poddał analizie dwa dzienniki nastolatków przebywających w czasie wojny w getcie w Łodzi i w Wilnie. Pytania badawcze dotyczyły rodzaju podejmowanych strategii zaradczych w obliczu zagłady nie tylko własnej, także kultury i całej społeczności, sposobów utrzymania poczucia sprawstwa $\mathrm{w}$ warunkach getta, przejawów odporności psychicznej nastolatka oraz sposobów konstruowania w tych warunkach tożsamości, zwłaszcza perspektywy czasowej. W opracowywaniu dzienników autor korzystał z teorii odporności psychicznej w ciągu życia (Klohnen 1996; Masten, Wright 2010), teorii stresu Lazarusa i Folkmana (1984) oraz koncepcji rozwoju tożsamości w adolescencji (Erikson 2004; McLean 2009). W pierwszym etapie pracy nad tekstem Cohler przedstawia warunki panujące w getcie łódzkim jako kontekst analizy i interpretacji materiału badawczego. Następnie opisuje zawartość dziennika Dawida Sierakowiaka pod kątem pytań badawczych, z użyciem przyjętych podejść teoretycznych. Polega to na poszukiwaniu w tekście przejawów strategii zaradczych, odporności, poczucia sprawstwa oraz koncepcji własnej tożsamości (przede wszystkim narracyjnej), w czym korzysta z teoretycznych wskazówek dotyczących sposobów ich przejawiania się oraz wzajemnych związków 
między nimi, także związków z kontekstem społecznym i sytuacyjnym. Taką samą procedurę stosuje autor odnośnie do dziennika Izaaka Rudaszewskiego z wileńskiego getta. Aby wyciągnąć wnioski, porównuje oba dzienniki, szukając przede wszystkim obszarów wspólnych. Konkluzje Cohlera wpisują się w nurt badań także zastosowań - psychologii wykazujących dobroczynną rolę pisania dzienników (Pennebaker 1997). Autor dostarcza liczne argumenty na rzecz tej tezy: pisanie dziennika pomaga w zarządzaniu nieszczęściem i stratą (w tym wypadku ekstremalną), w utrzymaniu spójności, także odporności, inicjuje strategie radzenia sobie w oparciu o poczucie własnej skuteczności.

W porównaniu z pionierskimi dokonaniami Ch. Bühler praca Cohlera ma większe zaplecze teoretyczne, a także dedukcyjny sposób wnioskowania. „Nałożona” na tekst teoria wyznacza to, czego należy poszukiwać w tekście i jak owe znaleziska interpretować. Bühler — jako reprezentantka pozytywizmu - wychodzi od faktów zaczerpniętych z biografii w ich poszczególnych aspektach. Na ich podstawie proponuje model, który następnie uzasadnia w oparciu o analizowane biografie. Trudno oprzeć się wrażeniu, że dokonywane przez nią streszczenia i przytaczane fragmenty dobierane są w taki sposób, żeby potwierdzić model. Dotyczy to zwłaszcza opracowania tak pogmatwanych losów, jak Oskara Wilde’a czy Isadory Duncan, w wypadku których można rozważać różne możliwości interpretacyjne. Natomiast uznanie może budzić rozmach pracy i systematyczność podejścia w opracowaniu ogromnego materiału, które doprowadziły do stworzenia pierwszego modelu rozwoju w ciągu życia.

Współczesne badania nad historią życia osadzone są w jakościowych metodach narracyjnych oraz teoretycznych ujęciach narracyjnej tożsamości. Najbardziej znanym przedstawicielem tego nurtu jest Dan McAdams, który rozpoczął $\mathrm{w}$ latach osiemdziesiątych ubiegłego wieku badania nad narracyjną tożsamością metodą metafory książki (McAdams 1987). Współracował on między innymi $-\mathrm{z}$ A. Lieblich, która wraz ze współautorami zaproponowała cztery modele analizy tekstu powstałe z kombinacji dwóch kryteriów: czytanie nastawione na ujęcie holistyczne lub kategorialne oraz czytanie nastawione na tematy lub na formę wypowiedzi (Lieblich, Tuval-Maschiach, Zilber 1998). Ustalenia autorów dotyczące analizy tematycznej są często wykorzystywane w psychologicznych badaniach jakościowych (Azmitia, Ittel, Radmacher 2005; Androutsopoulou 2015). Opracowywanie materiału odbywa się poprzez realizację następujących kroków:

1. Uważne i empatyczne czytanie całości mające na celu pierwszą ewaluację materiału (czy jest „dobry” z punktu widzenia celów badawczych).

2. Poszukiwanie odstępstw i niezwykłych cech historii, na przykład sprzeczności lub niekończących się opisów.

3. Wynotowanie miejsc poświęconych poszczególnym aspektom historii, powtórzeniom, szczegółom, pominięciom albo bardzo krótkim wzmiankom.

4. Ustalenie tematów i kilkakrotne ich czytanie. 
5. Prześledzenie każdego tematu przez całą historię z zanotowaniem początku i końca tematów. Wynotowanie epizodów, które wydają się sprzeczne z tematem pod względem treści, nastroju i oceny narratora (Androutsopoulou 2015, s. 136).

Takie opracowanie materiału związane jest z problemami badawczymi dotyczącymi narracyjnej tożsamości oraz dialogowego self (Hermans 2008), stąd nacisk na sprzeczności, pominięcia i tym podobne.

Przykładem narracyjnych badań nad tożsamością z użyciem tekstów pisanych jest praca McLean i Pratta (2006), której przedmiotem była rola autorefleksyjności ukierunkowanej na odkrywanie sensów w kształtowaniu tożsamości w okresie wkraczania w dorosłość. Wykorzystano dwa podejścia teoretyczne: tradycyjną koncepcję Eriksona (2004) oraz koncepcję narracyjnej tożsamości (McAdams 2001). Zadaniem osób badanych było napisanie wydarzeń składających się na historię życia, które stanowiły w tej historii punkt zwrotny. Poza tym osoby wypełniały kwestionariusze mierzące status tożsamości w ujęciu Eriksona, generatywność i optymizm. Badania kwestionariuszowe prowadzone były podłużnie od okresu wczesnej adolescencji. Narracje były pisane, gdy osoby badane miały 23 lata. Otrzymane historie zostały zakodowane przez niezależnych sędziów (obliczono rzetelność ich ocen) ze względu na:

— rodzaj historii, zgodnie z definicjami każdego rodzaju historii;

- ton emocjonalny historii (na skalach od 0 do 3 oznaczano ton końca historii, po czym odejmowano ton początku);

- poziom refleksyjności (meaning-making): szacowany na skalach od 0 do 3 poziom złożoności rozumowania dotyczącego odkrywania (rozumienia) sensu wydarzenia.

Zestawienie wyników badań kwestionariuszowych z narracyjnymi (korelacje i interkorelacje) potwierdziły przypuszczenie, że dojrzalszemu statusowi tożsamości towarzyszy większa złożoność refleksji nad znaczeniem. Złożoność tworzenia znaczenia (meaning-making) wiąże się u dwudziestotrzylatków z generatywnością i optymizmem. Nie jest ona jednak związana z narracją o sukcesach i osiągnięciach, lecz z historiami skoncentrowanymi na doświadczaniu śmiertelności oraz wybawienia z opresji (redemption).

Powyższe badanie tematycznie wiąże się z analizami Ch. Bühler, które również dotyczą problematyki sensu (przeznaczenia), tyle że w ogólniejszym wymiarze: sensu całego życia. Zestawienie obu prac pokazuje, jakim rygorom metodologicznym poddają się współczesne, psychologiczne badania jakościowe. Dotyczy to nie tylko zaangażowania statystycznych procedur, zwiększania rzetelności i trafności pomiaru (sędziowie kompetentni), lecz także dyscypliny teoretycznej. Żeby sprostać tym wymaganiom, problemy badawcze formułowane są węziej.

Psychologiczne badania historii życia mają już swoją obszerną literaturę zawierającą ustalenia na temat rozwoju tożsamości narracyjnej oraz jej funkcji adaptacyjnych (McAdams, McLean 2013). W wyniku prowadzonych od ponad 25 
lat badań w tej dziedzinie ustalone zostały wymiary spójności struktury narra$\mathrm{cji}^{3}$ oraz typy tematów poruszanych w historii życia, istotnych z punktu widzenia opisu narracyjnej tożsamości. Należą do nich: wybawienie z trudności (redemption), straty i utrudnienia, autonomiczne działania kreujące własne życie, bliskie związki, samopoznanie, tworzenie znaczeń (meanig-making), spójne i pozytywne decyzje oraz efektywność i sprawność działania. Są one podstawą kodowania narracji (ibidem). Trzeba jednak zastrzec, że większość z tych ustaleń wynika $\mathrm{z}$ badań nad opowiadaną historią życia. W badaniach tekstów pisanych - jak powyższe McLean i Pratta - wykorzystuje się te ustalenia w tym samym stopniu, co w badaniach nad opowiadanym życiorysem. Świadczy to o tym, że nie uwzględnia się w tym podejściu specyfiki dokumentu osobistego. Nie wykorzystuje się także jako źródła danych gotowych tekstów osobistych tak, jak to było w badaniach Ch. Bühler czy B.J. Cohlera.

\section{llustracja empiryczna. Propozycja autorska}

Do pełniejszego ukazania sposobów pracy nad tekstem wykorzystywanych w powyżej opisanych badaniach nad tożsamością narracyjną posłużmy się przykładem analizy i interpretacji tekstu pamiętnika. Jest to tekst nadesłany na konkurs ogłoszony w 2005 roku przez Instytut Socjologii Uniwersytetu Wrocławskiego na temat europejskości Polaków. Tytuł ulotki konkursowej brzmiał: „Konkurs na pamiętnik, wspomnienie, pisemną wypowiedź: Polacy w Europie - Europa wśród Polaków. W poszukiwaniu własnych korzeni". Jednym z doprecyzowujących było pytanie: „Jak Państwa życie rodzinne, zawodowe, towarzyskie układało się na tle zmian w Polsce i w Europie w ciągu ostatnich 30 lat?" Sądząc z treści wspomnienia, autor potraktował to pytanie jako bodziec narracyjny.

Zaproponowana analiza i interpretacja jest jedynie ilustracją prezentowanej metody („materiałem szkoleniowym”), nie jest fragmentem pracy badawczej. Wszystkie elementy - problem badawczy, wyniki analizy oraz interpretacja powstały na potrzebę zapoznania czytelnika $\mathrm{z}$ metodą badań nad narracyjną tożsamością McAdamsa.

\section{Problem badawczy}

$\mathrm{Z}$ uwagi na to, że materiał wykorzystany jest do analiz psychologicznych, postawmy psychologiczny problem badawczy: w jaki sposób narrator doświadcza siebie w kontekście przynależności do Europy?

3 Temporalny, przyczynowy, tematyczny i kulturowy (Habermas, Bluck 2000). 
Sposób doświadczania siebie jest ujęty - w tym wypadku - w narracyjny sposób myślenia polegający na konstruowaniu historii nadających kształt naszym myślom, spostrzeżeniom, uczuciom (Bruner 1992). Historie te symbolizują sensy (znaczenia) osobiste w wymiarach: biologicznym, społecznym, podmiotowym (psychologicznym) oraz egzystencjalnym (duchowym) (Straś-Romanowska 1992). Owe znaczenia są ustosunkowaniami (przeżyciami) subiektywnymi, wobec czego przyjęta perspektywa badawcza jest perspektywą subiektywną, a właściwym przedmiotem badań jest tożsamość narracyjna (jej opis). Możemy zatem doprecyzować problem badawczy:

W jaki sposób przedstawiona narracja określa tożsamość osobistą autora:

- jaki jest sposób i zakres porządkowania i integrowania doświadczeń;

— jaki jest poziom refleksyjności i autorefleksyjności autora;

- jaki sens nadawany jest doświadczeniom ( $w$ wymiarze społecznym, podmiotowym i transcendentnym);

- na ile narracja ujawnia koncepcję całości życia (jego sensu), jakie elementy i właściwości narracji składają się na poczucie jedności i celowości życia?

Ze względu na cel konkursu, w odpowiedzi na powyższe pytania uwzględnione powinno być tło kulturowo-historyczne zaznaczone przez autora wspomnień.

Należy zaznaczyć, że kategoria „znaczenie osobiste” nie jest tym samym, co znaczenie konwencjonalne (kulturowe). Jest ono indywidualnym, subiektywnym przeżyciem, w którym wyraża się całościowe (we wszystkich wymiarach osoby) ustosunkowanie (egzystowanie). Zadaniem badacza jest w tej sytuacji opis owych ustosunkowań. Znaczenia osobiste wiążą się ze znaczeniami konwencjonalnymi, które w subiektywnym przeżyciu nabierają indywidualnego charakteru przez ich związanie z pozostałymi wymiarami osoby (psychologicznym, biologicznym, duchowym $)^{4}$.

\section{Osoba badana}

Autorem pamiętnika jest mężczyzna urodzony około 1960 roku, mieszkający w Polsce. Jego wspomnienia obejmują okres od dzieciństwa (okres szkolny, początek lat siedemdziesiątych) do około 45 roku życia. Wydarzenia historyczne (głównie dotyczące Polski) zaznaczone we wspomnieniach to: narodziny Solidarności (1980), I Zjazd Solidarności, wprowadzenie stanu wojennego (grudzień 1981), wizyta papieża Jana Pawła II (nie wiadomo która, prawdopodobnie pierwsza 1979 lub trzecia - 1987), „okrągły stół” (kwiecień 1989), upadek muru berlińskiego (listopad 1989), wybór Lecha Wałęsy na prezydenta Polski, wybór Aleksandra

${ }^{4}$ Metoda analizy i interpretacji narracji bazująca na teoretycznym modelu Straś-Romanowskiej została opisana w artykule: B. Bartosz, M. Żurko (2014) Badania narracyjne w podejściu interpretatywnym - wskazówka metodologiczna. Teraźniejszość, „Człowiek, Edukacja” 68, nr 4, s. 19-38. 
Kwaśniewskiego na prezydenta Polski (1995), wojna na bałkanach (1991-1995), wstąpienie Polski do Unii Europejskiej (2004, zaznaczone tylko jako data, bez opisu). Autor odnotowuje także zjawisko emigracji ekonomicznej - bezpośrednio po informacji o objęciu urzędu prezydenta przez A. Kwaśniewskiego - oraz zmian oferty handlowej: „w sklepach, które powstawały jak "grzyby po deszczu“ pojawiły się towary o których jeszcze 10 lat temu mogliśmy tylko pomarzyć”. W dalszej części wspomnień odnotowuje zmiany cywilizacyjne: informatyzację, mobilną komunikację, rozwój transportu i wymiany międzynarodowej. Wszystko to stanowi kontekst wydarzeń autobiograficznych. Narrator opisuje chronologiczne wydarzenia $\mathrm{z}$ dzieciństwa: atmosferę domu rodzinnego, przynależność do harcerstwa i ministrantów, sukcesy sportowe, wyróżnienia, śmierć mamy i jej konsekwencje; następnie młodość: udział w zawodach sportowych, pierwszą miłość, wstąpienie do wojska, służbę podczas stanu wojennego; dorosłość: powrót z wojska, założenie rodziny, narodziny dzieci, leczenie odwykowe, awans w pracy, zawał, wyjazd z rodziną na wczasy w Alpy.

\section{Analiza}

Sposób analizy tekstu stanowi połączenie wskazówek sformułowanych przez Lieblich (op. cit.), metody analizy narracji McAdamsa oraz własnych strategii pracy nad tekstem, osadzonych w teorii znaczeń osobistych Straś-Romanowskiej (1992). Analiza powinna być dokonana przez kilku sędziów kompetentnych (przeszkolonych w zakresie tego typu analiz). W badaniach jakościowych nad okresem dorastania korzysta się często z sędziowania przez studentów (Azmitia 2005). Mimo przygotowania z zakresu psychologii rozwoju i osobowości, w pracy nad narracjami osób dorosłych lepiej nie korzystać z pomocy studentów (ze względu na trudność w przyjęciu perspektywy narratora przez osobę, która nie przeżyła podobnych doświadczeń).

Krok 1: uważne i empatyczne czytanie całości mające na celu odnotowanie pierwszego wrażenia (pierwsza ewaluacja materiału) z punktu widzenia problemu badawczego. Ważne jest, żeby w opracowaniu materiału wyjść od całości, starając się odczytać główne przesłanie tekstu.

Krok 2: zaznaczenie form wypowiedzi: opis, argumentacja, narracja. Dzięki temu w tekście pokazują się poszczególne wydarzenia (części narracyjne) oraz towarzyszące im komentarze (opis, argumentacja). Tekst zostaje podzielony na narracyjne jednostki analizy (zob. załącznik). Ponieważ analizy dokonują sędziowie kompetentni, niezbędne jest wspólne ustalenie listy wydarzeń i opatrzenie ich odpowiednimi tytułami. Chodzi o to, aby w dalszych krokach analizy sędziowie kompetentni pracowali na ujednoliconym materiale. 
Krok 3: uporządkowanie jednostek narracyjnych według typów tematów poruszanych w historiach życia (McAdams). Aby było to możliwe, należy zdefiniować każdy rodzaj tematu:

- Wybawienie: przejście narratora (bohatera) ze stanu złego do pozytywnego, dobrego. Może to być: ofiara (bohater jest w stałej złej sytuacji, ale łączy się to z odnoszonymi korzyściami), odzyskanie czegoś, co się wcześniej utraciło, wzrost (poprawa siebie w aspekcie psychicznym, fizycznym, podmiotowym), nauczenie się czegoś, zdobycie mądrości (też: umiejętności).

- Kontaminacja: przejście ze stanu dobrego do złego, zaznaczone jako negacja poprzedniego, korzystnego stanu lub jako zablokowanie dobrych wspomnień (narrator nie jest w stanie myśleć dobrze o czymś), czuje się przytłoczony obecnym, złym stanem; może to być: wiktymizacja, zdrada, strata, awaria, choroba lub uraz, rozczarowanie, utrata złudzeń.

- Wzrost: stopień, w jakim bohater jest autonomiczny i ma moc wpływania na własne życie. Wzrost może dotyczyć: samosterowności (władania sobą), powiększania prestiżu, osiągnięć, samotranscendencji, mistrzostwa (w odniesieniu do siebie).

- Wspólnota, bliskość: bohater jest motywowany do tworzenia bliskich relacji: przyjaźni, miłości, wspierania i troski o innych, poczucia jedności z innymi.

- Samopoznanie: narracja wyraża eksplorację siebie, jest okazją do autorefleksji, stawiania pytań, rozumienia siebie. Historie tego rodzaju opowiadają najczęściej o przemianie bohatera, zwierają punkty zwrotne w historii.

- Spójne, pozytywne rozwiązania: bohater podejmuje postanowienia, które zamykają w pozytywny sposób historię i otwierają przed nim nowe możliwości. Obecność tego typu historii jest skorelowana z odpornością ego i zdolnościami radzenia sobie ze stresem.

- Wydajność: bohater osiąga wartościowe wyniki, jest skuteczny i sprawny. Tego typu historie pojawiają się często w narracjach sportowców.

- Odkrywanie znaczeń: stopień, w jakim narrator wyciąga wnioski z historii, intencjonalnie się ustosunkowując do wydarzeń. Autor opowiada historię, która symbolizuje istotne wartości z punktu widzenia całości życia. W tych historiach jest wyrażona wprost autorefleksja o różnej głębokości i złożoności.

Na potrzeby analizy zaproponowana została tabela zawierająca typy historii, refleksyjność towarzyszącą (bądź nie) opowiadanym wydarzeniom oraz związane z nimi emocje.

Tab. 1. Analiza wspomnień „Cegły”

\begin{tabular}{|l|c|c|c|}
\hline \multicolumn{1}{|c|}{ Rodzaj historii: wydarzenia } & $\begin{array}{c}\text { Poziom } \\
\text { refleksyjności }\end{array}$ & Ton emocjonalny & $\begin{array}{c}\text { Kontekst społecz- } \\
\text { no-historyczny }\end{array}$ \\
\hline $\begin{array}{l}\text { Wybawienie } \\
\text { 1. samodzielność i zaradność po } \\
\text { śmierci mamy }\end{array}$ & & uznanie & \\
\hline
\end{tabular}




\begin{tabular}{|c|c|c|c|}
\hline $\begin{array}{l}\text { 2. leczenie odwykowe, awans w pracy, } \\
\text { odbudowa relacji rodzinnych }\end{array}$ & & $\begin{array}{c}\text { zadowolenie } \\
\text { zaskoczenie }\end{array}$ & $\begin{array}{l}\text { wzrost ekono- } \\
\text { miczny w Polsce }\end{array}$ \\
\hline $\begin{array}{l}\text { Kontaminacja } \\
\text { 1. śmierć mamy }\end{array}$ & & smutek & \\
\hline 2. przyjaciele ze szkoły, strata kontaktu & & & $\begin{array}{l}\text { postawy egali- } \\
\text { tarne w relacjach } \\
\text { społecznych } \\
\text { w komunizmie }\end{array}$ \\
\hline $\begin{array}{l}\text { 3. Ute: trudności w kontaktach, } \\
\text { urwanie kontaktu }\end{array}$ & & $\begin{array}{c}\text { rozżalenie } \\
\text { tęsknota }\end{array}$ & stan wojenny \\
\hline $\begin{array}{l}\text { 4. małżeństwa w rodzinie (utrata } \\
\text { bliskości) }\end{array}$ & & osamotnienie & $\begin{array}{c}\text { narodziny } \\
\text { Solidarności, } \\
\text { chaos }\end{array}$ \\
\hline 5. stan wojenny & $\begin{array}{c}\text { pytania o relacje } \\
\text { między jednost- } \\
\text { ką a ojczyzną }\end{array}$ & \begin{tabular}{|c|} 
bezradność \\
poczucie nie- \\
sprawiedliwości
\end{tabular} & \\
\hline 6. odmowa wydania paszportu & & zagrożenie & \\
\hline 7. uniemożliwienie trenowania sportu & & & stan wojenny \\
\hline 8. picie & & & $\begin{array}{l}\text { zarzuty pod adre- } \\
\text { sem żołnierzy } \\
\text { stanu wojennego }\end{array}$ \\
\hline 9. brak porozumienia $\mathrm{z}$ żoną & & & $\begin{array}{l}\text { wojna na } \\
\text { Bałkanach }\end{array}$ \\
\hline 10. zawał & & ból, dyskomfort & \\
\hline \multicolumn{4}{|l|}{ Wzrost } \\
\hline $\begin{array}{l}\text { Wspólnota, bliskość } \\
\text { 1. przyjaciele ze szkoły }\end{array}$ & & sentymentalność & \\
\hline 2. Ute & & entuzjazm & \\
\hline 3. ksiądz (autorytet okresu dorastania) & & sentymentalność & \\
\hline 4. poznanie żony & & & $\begin{array}{c}\text { koniec } \\
\text { komunizmu }\end{array}$ \\
\hline 5. narodziny córki & & radość & \\
\hline 6. narodziny kolejnych dzieci & & & $\begin{array}{c}\text { prezydentura } \\
\text { Kwaśniewskiego, } \\
\text { zmiany ekono- } \\
\text { miczno-społeczne, } \\
\text { emigracja } \\
\text { zarobkowa }\end{array}$ \\
\hline 7. relacja z młodszą siostrą & & $\begin{array}{c}\text { miłość, } \\
\text { wdzięczność }\end{array}$ & \\
\hline 8. kariera sportowa córki & & $\begin{array}{l}\text { radość, duma, } \\
\text { bliskość }\end{array}$ & \\
\hline $\begin{array}{l}\text { Samopoznanie } \\
\text { picie, przyczyny }\end{array}$ & $\begin{array}{c}\text { przypuszczenie, } \\
\text { że nie radzi sobie } \\
\text { na skutek szyb- } \\
\text { kich zmian }\end{array}$ & & transformacja \\
\hline
\end{tabular}




\begin{tabular}{|c|c|c|c|}
\hline $\begin{array}{l}\text { Spójne i pozytywne rozwiązania } \\
\text { 1. zgłoszenie się do wojska (trenowa- } \\
\text { nie sportu) }\end{array}$ & & & $\begin{array}{l}\text { narodziny } \\
\text { Solidarności, } \\
\text { chaos }\end{array}$ \\
\hline 2. podjęcie pracy & & & $\begin{array}{l}\text { rozpad więzi } \\
\text { społecznych }\end{array}$ \\
\hline 3. wyjazd w Alpy & $\begin{array}{l}\text { nowe możliwości } \\
\text { kontaktowa- } \\
\text { nia się budzą } \\
\text { wspomnienia } \\
\text { o Ute, rozważa- } \\
\text { nie alternatywnej } \\
\text { biografii }\end{array}$ & $\begin{array}{l}\text { zadowolenie } \\
\text { przyjemność } \\
\text { nostalgia }\end{array}$ & $\begin{array}{l}\text { nowe rozwiąza- } \\
\text { nia techniczne, } \\
\text { bariery cywili- } \\
\text { zacyjne czasów } \\
\text { komunizmu }\end{array}$ \\
\hline $\begin{array}{l}\text { Efektywność i sprawność działania } \\
\text { 1. uczyłem się dobrze }\end{array}$ & $\begin{array}{c}\text { dostrzeganie } \\
\text { niespójności } \\
\text { świata komu- } \\
\text { nistycznego } \\
\text { i w konsekwencji } \\
\text { własnego }\end{array}$ & zadowolenie & $\begin{array}{l}\text { relatywizm czasów } \\
\text { komunizmu, brak } \\
\text { przywiązania } \\
\text { do zasad }\end{array}$ \\
\hline 2. zajęcia sportowe, zawody, nagrody & & $\begin{array}{l}\text { radość, duma, } \\
\text { entuzjazm }\end{array}$ & $\begin{array}{c}\text { wesołe życie } \\
\text { w PRL }\end{array}$ \\
\hline $\begin{array}{l}\text { 3. wybrano mnie na pre- } \\
\text { zesa ministrantów }\end{array}$ & & $\begin{array}{c}\text { zadowolenie, } \\
\text { uznanie }\end{array}$ & \\
\hline 4. zajęcia domowe & & $\begin{array}{l}\text { zadowolenie, } \\
\text { uznanie }\end{array}$ & \\
\hline $\begin{array}{l}\text { Tworzenie znaczeń (meanig-ma- } \\
\text { king) dotyczących całości tekstu } \\
\text { 1. wrogość w relacjach społecznych, } \\
\text { pozycja winnego, rozpad więzi } \\
\text { społecznych, krytycyzm wobec byłej } \\
\text { opozycji i wobec społeczeństwa }\end{array}$ & $\begin{array}{c}\text { ocena mo- } \\
\text { ralna siebie jako } \\
\text { żołnierza stanu } \\
\text { wojennego } \\
\text { (jest niewinny) }\end{array}$ & niechęć & transformacja \\
\hline 2. metafora cegły & $\begin{array}{c}\text { widzi siebie jak } \\
\text { zbędny element } \\
\text { czasów (złych), } \\
\text { które bezpowrot- } \\
\text { nie przeminęły }\end{array}$ & $\begin{array}{l}\text { smutek, } \\
\text { dezorientacja, } \\
\text { przygnębienie }\end{array}$ & transformacja \\
\hline $\begin{array}{l}\text { 3. widzenie siebie jako osoby uczestni- } \\
\text { czącej w zmianach w Polsce (w nie- } \\
\text { chcianej roli), chce być doceniony } \\
\text { (szanowany), chciałby mieć wybór } \\
\text { i decydować, a nie } \\
\text { walczyć (jak żołnierz) }\end{array}$ & $\begin{array}{c}\text { stawia pytania, } \\
\text { nie odpowiada } \\
\text { na nie, konstatu- } \\
\text { je, że jedni mają } \\
\text { szczęście, a inni } \\
\text { nie }\end{array}$ & dezorientacja & transformacja \\
\hline
\end{tabular}

Źródło: opracowanie własne.

Analiza może mieć prostszą formę: zamiast nazywania uczuć i streszczania refleksji autora można zastosować skale ocen. Do refleksyjności 0-3, gdzie 0 - brak refleksji, 1 - pytania, wątpliwości, 2 - proste konstatacje (np. „nie można zbyt wiele oczekiwać od życia”), 3 - złożona, pogłębiona refleksja. 
Do uczuć może być to szacowanie tonu emocjonalnego (McLean, Pratt, op. cit.), gdzie otrzymujemy skalę od (-3) do 3. Badanie tonu emocjonalnego stosuje się wobec dłużej trwających, bardziej rozbudowanych wydarzeń, w których możliwe jest odnotowanie dynamiki emocjonalnej. Jeśli narrator lakonicznie, krótko opisuje wydarzenie, może być to trudne. $\mathrm{W}$ takim wypadku można poprzestać na znaku emocji, stosując skalę od (-2) do 2, gdzie (-2) - emocja silnie negatywna, (-1) - negatywna, 0 - brak ustosunkowania emocjonalnego, 1 - emocja pozytywna, 2 - emocja silnie pozytywna. To, w jaki sposób potraktuje się oba składniki analizy (refleksyjność, emocjonalność), zależy od problemu badawczego. Stosowanie skal jest znaczącą redukcją danych, niemniej pozwala na dokonywanie analiz statystycznych niezbędnych do porównywania danych pochodzących od różnych autorów.

Krok 4: obliczenie zgodności między sędziami (test W. Kendalla). Aby było to możliwe, wszystkie dane nominalne muszą być przekształcone na skale porządkowe. Kolejnym warunkiem jest niezależność ocen sędziów. O ile w trzecim kroku pracuje się nad wspólnymi ustaleniami (dotyczącymi tego, jakie są epizody narracyjne w tekście), o tyle przyporządkowywanie epizodów do tematów, szacowanie refleksyjności i emocjonalności musi być prowadzone przez każdego sędziego oddzielnie. Po obliczeniu zgodności otrzymujemy tabelę zawierającą pozycje, co do których sędziowie byli zgodni w największym stopniu.

Ponieważ analizowany przykład jest ilustracją metody pracy nad tekstem, krok czwarty jest jedynie zasygnalizowany, a nie zrealizowany.

\section{Interpretacja}

Po uzyskaniu danych z analizy, co do których sędziowie kompetentni są zgodni, można rozpocząć interpretację. Powracamy w niej do szczegółowych pytań badawczych. W odpowiedzi na nie bierzemy pod uwagę liczbę historii przyporządkowanych do każdego tematu. Stąd wyciągamy wnioski o temacie (tematach) wiodących oraz pominiętych. Odnosząc się do przedstawionej w tabeli analizy (tu potraktowanej roboczo jako analiza zbiorcza wynikająca z porównań między sędziami kompetentnymi), można na przykład zauważyć, że dominują historie kontaminacyjne o doznawanych stratach i przeszkodach (dziesięć epizodów, w tym najdłuższa historia o nieszczęśliwej miłości), następnie o związkach (osiem epizodów) oraz dotyczących sprawności działania (cztery krótkie epizody). Nie odnaleziono historii dotyczących wzrostu podmiotowego oraz wskazano jedną dotyczącą samopoznania. Refleksyjność towarzysząca wydarzeniom pojawia się rzadko i jest mało rozwinięta (ma formę pytań bez odpowiedzi lub prostych, ogólnych konstatacji). W tekście są trzy fragmenty, w których autor dokonuje podsumowujących refleksji. Pierwszy dotyczy niedogodności schyłku komunizmu i ma formę retorycznych pytań, którym towarzyszą uczucia bezradności 
i niesprawiedliwości. Kolejny pojawia się w związku z kłopotami rodzinnymi i piciem (metafora cegły z muru berlińskiego), a ostatni w części końcowej tekstu i ma formę podsumowania całości. Tutaj także pojawiają się pytania bez odpowiedzi, ogólny wniosek (jedni mają szczęście, inni nie) oraz postulat dotyczący zwiększenia samosterowności. Po prześledzeniu towarzyszących wydarzeniom uczuć (w większości negatywne; pozytywne towarzyszą historiom o efektywności i sprawności działania oraz niektórym dotyczącym związków) możemy odpowiedzieć na pytanie o sposób przeżywania siebie jako bohatera własnej narracji. W tym wypadku dominują przeżycia niezawinionej i niezrozumiałej straty wynikającej z wydarzeń związanych ze schyłkiem komunizmu oraz byciem reprezentantem pokolenia transformacji. Pozytywne doświadczenia siebie wiążą się ze sprawnością (typowe zjawisko w narracjach sportowców; Carless, Douglas 2013) oraz z przeżywaniem siebie w niektórych bliskich relacjach (miłość do Ute, relacja z siostrą, z córką jako kontunuatorką zaangażowań narratora). Przewaga historii kontaminacyjnych może wiązać się z niską samooceną oraz skłonnościami depresyjnymi (Adler, Kissler, McAdams 2006). Uboga refleksyjność może świadczyć o niskiej generatywności ${ }^{5}$ (Pratt et al. 1999). Analizowana narracja jest także uboga w historie związane z samopoznaniem, co może wiązać się z niskim stopniem rozwoju ego (Loevinger 1979, za: Oleś 2000; Adler, Wagner, McAdams 2007). Należy jednak uwzględnić, że skrótowość i lakoniczność narracji może wynikać ze sposobu zrozumienia przez narratora celu konkursu, na który napisany został tekst. Wybór wydarzeń i sposób ich przedstawienia mógł być dokonywany pod kątem wyobrażonych potrzeb socjologów. Dlatego ustalenia psychologów wynikające z badań nad narracjami pisanymi na ich prośbę (wywoływanymi) powinny być stosowane z dużą ostrożnością wobec tekstów wywoływanych przez socjologów. Tego typu ograniczenia nie miałyby miejsca, gdyby przedmiotem badań były dokumenty osobiste pisane z potrzeby autorów, a nie badaczy. W odniesieniu do problemu głównego (przeżywanie swojego losu w kontekście europejskim) można prześledzić kontekst społeczno-historyczny towarzyszący poszczególnym epizodom (tabela, kolumna czwarta) oraz rodzajom historii, ze szczególnym uwzględnieniem pojawiających się wprost wątków europejskich. Widać skoncentrowanie narratora na wydarzeniach zachodzących w Polsce, dotyczących przede wszystkim schyłku komunizmu i zmian po jego upadku. Narrator nie nawiązuje do wydarzeń na wschód od Polski, co sprawia wrażenie, że Europa jest $-\mathrm{z}$ jego punktu widzenia - raczej na Zachodzie. Można przypuszczać, w uproszczeniu, że koncepcja losu bohatera wspomnień to nie do końca zrozumiała (a już na pewno nie zamierzona) historia człowieka, przez którego życie przetoczyło się „,koło historii”, rujnując młodzieńcze marzenia (o sportowej karierze i wielkiej miłości), podważając

5 Termin zaczerpnięty z teorii E. Eriksona, oznaczający charakterystyczną dla średniej dorosłości kreatywność, twórczość w różnych dziedzinach życia: w życiu zawodowym, rodzinnym, obywatelskim i podmiotowym (dotyczącym Ja). 
pozycję społeczną i poczucie samoakceptacji, niszcząc witalne zdolności do obrony (picie) i odsuwając w zupełny niebyt kraj lat dziecinnych. Ten pesymistyczny obraz przełamywany jest uczuciami radości i dumy z córki, która - być może zrealizuje marzenia ojca, oraz zaznaczonej w końcu wspomnień słabej nadziei, że wszystko jeszcze może się zmienić.

Powyższa interpretacja jest jedynie przykładem pokazującym możliwości, jakie daje stosowanie metod inspirowanych dorobkiem McAdamsa oraz innych badaczy zaprezentowanego nurtu. Istotą przedstawionej metody jest śledzenie rodzajów historii ustanawiających tożsamość narracyjną oraz towarzyszącej im refleksyjności. W efekcie możliwe jest odtworzenie indywidualnego, subiektywnego przeżywania siebie jako bohatera opowiedzianych historii.

\section{Podsumowanie}

Jeśli ująć dokument osobisty $\mathrm{w}$ jego istocie, należy potraktować go jako tekst symbolizuący zawarty w nim sens (tu: osobisty). Wobec tego oczywistym podejściem jest jego interpretacja. Aby wydobyć podmiotowe sensy, trzeba jednak odróżnić w tekście to, co jest rezultatem świadomej intencji autora od automatycznych regulacji wynikających z działania schematycznych reprezentacji umysłowych. Dlatego użyteczna w interpretacji tekstu ukierunkowanej na odkrycie sensu jest znajomość ustaleń badaczy reprezentujących podejście ilościowe, wyjaśniające (lub scjentystyczne, nomotetyczne). Coraz więcej psychologów jest zdania, że można łączyć podejście ilościowe z jakościowym (Łaguna, Stemplewska-Żakowicz 2012).

Małe zainteresowanie dokumentami osobistymi w psychologii współczesnej można łączyć z położeniem nacisku na ustalanie prawidłowości w zakresie automatycznej regulacji zachowania. Możliwości, jakie pojawiły się w badaniach mechanizmów mózgowych $\mathrm{w}$ związku $\mathrm{z}$ rozwojem nowoczesnych narzędzi badawczych, sprawiły, że psychologia ma coraz więcej wspólnego z naukami przyrodniczymi. Dynamicznie rozwijają się kognitywistyka i neuropsychologia, natomiast żmudne badania nad znaczeniami tekstów to zajęcie raczej niszowe. Warto zauważyć, że jakościowym badaniom narracyjnym towarzyszy dbałość o warunki walidacji, a stosowana metoda badawcza jest spójna z przyjętą teorią przedmiotu badań. To, co wiązałabym ze specyfiką badań jakościowych nad tekstem w psychologii, dotyczy przede wszystkim dbałości o poprawność warsztatową. Psychologowie jakościowi usiłują sprostać wysokim wymaganiom co do procedur badawczych oraz jakości stosowanych narzędzi analizy i interpretacji. Mimo to traktowani są z dużym dystansem, a ich publikacje nie mają zazwyczaj wysokiej rangi (są rzadko cytowane).

Na koniec wypada zaznaczyć wagę wpływu socjologii na rozwój psychologicznych badań nad narracją, zwłaszcza w Polsce. Dotyczy to nie tylko doniosłości 
spuścizny Floriana Znanieckiego, której wpływ na nauki społeczne jest trudny do przecenienia. Opublikowana w 1990 roku Metoda biograficzna w socjologii pod redakcją Jana Włodarka i Marka Ziółkowskiego stała się jedną z podstawowych pozycji inspirujących pierwsze w Polsce psychologiczne badania narracyjne w podejściu interpretatywnym oraz obowiązkową lekturą dla większości uczestników cyklu konferencji poświęconych metodzie narracyjnej w psychologii w latach 1999-2009. Nietrudno także zauważyć związki badań McAdamsa z metodą „life-history” stosowaną w socjologii. Wydaje się, że współpraca w obszarze badań jakościowych między psychologami a socjologami może w dalszym ciągu owocować wartościowymi rezultatami.

\section{Bibliografia}

Adler J.M., Kissel E., McAdams D.P. (2006), Emerging from the CAVE: Attributional style and the narrative study of identity in midlife adults, „Cognitive Therapy and research” 30 (1).

Adler J.M., Wagner J.W., McAdams D. (2007), Personality and the coherence of psychotherapy narratives, „Journal of Research in Personality” 41.

Androutsopoulou A. (2015), Moments of Meaning: Identifying Inner Voices in the Autobiographical Texts of 'Mark', „Qualitative Psychology” 2 (2).

Azmitia M., Ittel A., Radmacher K. (2005), Narratives of friendship and self in adolescence, „New Direction for Child and Adolescent Development" 107.

Bartosz B. (2002), Doświadczanie macierzyństwa. Analiza narracji autobiograficznych, Wrocław.

Bartosz B., Żurko M. (2014), Badania narracyjne w podejściu interpretatywnym - wskazówka metodologiczna, „Teraźniejszość - Człowiek - Edukacja” 68 (4).

Bruner J.S. (1992), Życie jako narracja, „Kwartalnik Pedagogiczny” 2.

Bühler Ch. (1999), Bieg życia ludzkiego, przeł. E. Cichy, J. Jarosz, Warszawa.

Carless D., Douglas K. (2013), „In the boat" but "selling myself short”: stories, narratives, and identity Development in Elite Sport, „The Sport Psychologist” 27.

Cierpka A. (2004), Narracje rodzinne w procesie kształtowania się tożsamości, [w:] Narracja. Koncepcje i badania psychologiczne, red. E. Dryll, A. Cierpka, Warszawa.

Cohler Bertram J. (2012), Confronting destruction: social context and life story in the diaries of two adolescents in eastern european ghettos during the shoah, "American Journal of Orthopsychiatry" $82(2)$.

Dryll E. (2010), Wielkie i małe narracje w życiu człowieka, [w:] Badania narracyjne $w$ psychologii, red. M. Straś-Romanowska, B. Bartosz, M. Żurko, Warszawa.

Gawda B. (2010), Narracje o miłości osób antyspołecznych, [w:] Psychologia małych $i$ wielkich narracji, red. M. Straś-Romanowska, B. Bartosz, M. Żurko, Warszawa.

Gough B., Deatrick J.A. (2015), Qualitative health psychology research: diversity, power, and impact, „Health Psychology” 34 (4).

Jasielska A. (2010), Analiza narracji jako źródła wiedzy o emocjach. Prezentacja metody, [w:] Badania narracyjne w psychologii, red. M. Straś-Romanowska, B. Bartosz, M. Żurko, Warszawa.

Kruchowska E. (2010), Metoda wielostopniowej analizy i interpretacji hermeneutycznej materiału empirycznego, [w:] Badania narracyjne w psychologii, red. M. Straś-Romanowska, B. Bartosz, M. Żurko, Warszawa.

Lieblich A., Tuval-Maschiach R., Zilber T. (1998), Narrative Research: Reading, Analysis and Interpretation, Thousand Oaks. 
Łaguna M., Stemplewska-Żakowicz K. (2012), Możliwośćłączenia podejścia ilościowego i jakościowego w badaniach nad osobowością, „Przegląd Psychologiczny” 55 (2).

McAdams D. (1988), Power, Intimacy and the Life Story. Personological Inquiries into Identity, New York.

McAdams D. (2001), The psychology of life stories, „Rewiev of General Psychology” 5 (2).

McAdams D., McLean K. (2013), Narrative identity, „Current Directions in Psychological Science" 22 (3).

McLean Kate C., Breen A.V. (2009), Process and content of narrative identity development in adolescence: Gender and well-being, „Developmental Psychology” 45.

McLean Kate C., Pratt Michael W. (2006), Life's little (and big) lessons: identity statuses and meaningmaking in the turning point narratives of emerging adults, „Developmental Psychology” 42 (4).

Oleś P. (2000), Psychologia przełomu połowy życia, Lublin.

Opoczyńska M. (2008), Narracje w psychoterapii - ujęcie fenomenologiczne, [w:] Narracja. Teoria i praktyka, red. B. Janusz, K. Gdowska, B. de Barbaro, Kraków.

Pratt M.W. et al., (1999), Generativity and moral development as predictors of value-socialization narratives for young persons across the adult lifespan: From lessons learned to stories shared, "Psychology and Aging” 14.

Straś-Romanowska M. (1992), Los człowieka jako problem psychologiczny, Wrocław.

Straś-Romanowska M. (2000), O metodzie jakościowej w kontekście rozważań nad tożsamościa psychologii, [w:] Metody jakościowe w psychologii współczesnej, red. M. Straś-Romanowska, Wrocław.

Wójcik A., Dryll E. (2008), Formalna analiza języka blogów - prezentacja metody, [w:] Narracja. Teoria i praktyka, red. B. Janusz, K. Gdowska, B. de Barbaro, Kraków.

Żurko M. (2008), Wybrane metody analizy i interpretacji narracji autobiograficznej $w$ ujęciu hermeneutycznym, [w:] Narracja. Teoria i praktyka, red. B. Janusz, K. Gdowska, B. de Barbaro, Kraków.

\section{Selected psychological qualitative methods used for research into written text}

\section{Summary}

This article presents selected methods of written text analysis and interpretation using interpretative approach. This approach aims at discovering senses, i.e. personal attitudes (experiences). The work starts with classic theory of life-span development by Ch. Buhler and moves on to present contemporary research, published since 2005 , including psychological interpretation of B. Cohler's diaries from the ghetto, as well as studies in the area of narrative identity. The article includes an example of extensive analysis and interpretation of a diary, inspired by D. McAdams' method of Life Stories. Presented theoretical and practical proposals constitute a pragmatic contribution to interdisciplinary discussion on methods of using private documents as research material. 